\title{
Correlation of serum vitamin D with hip fracturesin males more than 50 years of age
}

\author{
Hari Krishna Mata ${ }^{1}$, Gupta DC ${ }^{2}$, Nataraj A.R ${ }^{3}$ \\ ${ }^{1}$ Dr Hari Krishna Mata, Assistant Professor, Department of Orthopaedics, SBKS Medical Institute and Research center, \\ Vadodara, Gujarat, India, ${ }^{2}$ Dr Dinesh Chand Gupta,Assistant professor, SBKS Medical Institute and Research Center, \\ Vadodara, Gujarat, India, ${ }^{3}$ Dr NatarajA.R, Associate Professor,Department of orthopaedics JIPMER Pondicherry.
}

Address for Correspondence: Dr.Hari Krishna Mata, Email: krisorthodoc@gmail.com, D-11, Staff Quarter, Sumandeep Vidhyapeeth, Piparia, Vadodara, India

\begin{abstract}
Introduction: Vitamin D is vital for bone health because it assists in the absorption and utilization of calcium. There are various studies in elderly females with hip fractures correlating the Vitamin D levels. But very few studies have evaluated the serum Vitamin D levels in males more than 50 years. Materials and Methods: Present study was conducted in the JIPMER Pondicherry between August 2012 and August 2013. A total of 41 male patients aged more than 50 years with fracture neck of femur and Intertrochanteric fracture were included. Blood samples were taken stored, processed and evaluated for vitamin D total (D2 and D3). The Values of Vitamin D obtained are shown into three groups as $0-20 \mathrm{ng} / \mathrm{ml}$-deficiency, 20-30ng/ml as insufficiency and $>30 \mathrm{ng} / \mathrm{ml}$ as normal Reference. Results: On analysis of Vitamin D we found that out of total 41 patients $9(22 \%)$ had vitamin D level <20ng /ml, 15(36\%) had levels between 20ng-30ng/ml and $17(41 \%)$ had $>30 \mathrm{ng} / \mathrm{ml}$. Of the 21 patients with Neck of femur fractures Vitamin D<20ng/ml are $6(28.6 \%), 20-30 \mathrm{ng} / \mathrm{ml}$ are $9(42.9)$ and $>30 \mathrm{ng} / \mathrm{ml}$ are $6(35.3)$.Vitamin D levels in 20 intertrochanteric fractures are $<20 \mathrm{ng} / \mathrm{ml}$ in $3(15 \%), 20-30 \mathrm{ng} / \mathrm{ml}$ in $6(35 \%)$ and $>30 \mathrm{ng} / \mathrm{ml}$ in $11(55 \%)$. Conclusion: We found 24 patients $(58 \%)$ have vitamin D level <30ng/ml, more in patients with neck femur fracture than intertrochanteric fractures. Present study found that there is no statistically significant correlation between the vitamin D level and proximal femoral fractures in elderly males $(\mathrm{p}=0.489)$.
\end{abstract}

Key words: Vitamin D level, Hip Fractures, Neck of femur fractures Intertrochanteric fractures.

\section{Introduction}

As elderly population continues to rise globally, osteoporosis became a major risk factor for fractures among elderly population in the modern world. Osteoporosis represents an increasingly important clinical and public health problem among older men and women [1].

Global demographic changes are expected to dramatically increase the burden of osteoporosis. By 2050 , it is estimated that the number of individuals aged 65 and older will be nearly 1.55 billion worldwide. The increase among the aged population would result in an almost four fold increase in the number of hip fractures worldwide [2].

Osteoporosis can affect any bone in the body . The most Manuscript received: $28^{\text {th }}$ Apr 2015

Reviewed: $14^{\text {th }}$ May 2015

Author Corrected: $24^{\text {th }}$ May 2015

Accepted for Publication: $5^{\text {th }}$ June 2015

International Journal of Medical Research and Review typical sites of fractures related to osteoporosis are hip, spine and wrist .Fracture sites have been shown to be related to age.Wrist fractures are common in 50yrs, spine in 60yrs and hip fractures in the 70yrs. The rates of all three types of fracture increases with age, but the increased risk with age is most pronounced with hip fractures [3].

For men the life time risk of osteoporotic fracture is about $13 \%$ after age 50 and the site specific fracture risks are $6 \%$ for the hip, $5 \%$ for the spine, and $3 \%$ for the wrist. Of the three most common sites for osteoporotic fractures hip fractures pose the most significant insult to health status of individual. Increased mortality with hip fractures is related to the coexistence of medical comorbidities [4].

The most significant increase in hip fracture rates is expected to occur in third world countries particularly 
in Asia [3]. An estimated 1.3-1.7 million hip fractures occurred worldwide in 1990. By 2025, this number is expected to increase to almost 3million [5].

Vitamin D is vital for bone health because it assists in the absorption and utilization of calcium. The major source of vitamin D is sunlight which the human body absorbs by exposure to sunlight through the conversion of precursors in the skin to active vitamin D [6].

Vitamin D deficiency is now recognized as a worldwide health problem, associated with poor dietary intake and inadequate exposure to sunshine, affecting upwards of a billion people $[7,8]$.

While considering the geographic distribution of osteoporosis and related fractures, deficiencies in vitamin D cannot be ignored. Vitamin D deficiency may predispose individuals to developing osteoporosis and subsequently osteoporotic fracture [9].

\section{Aim \&Objectives}

1. To assess the Serum Vitamin D level in males older than 50yrs with hipfractures.

2. To assess the correlation between Vitamin D and hip fractures in males older than $50 \mathrm{yr}$.

\section{Materials and Methods}

The present study was conducted in the Department of Orthopaedics in collaboration with the Department of Biochemistry, JIPMER Pondicherry, India. Approval was obtained prior to the study from JIPMER Scientific advisory committee and ethical clearances were obtained from Institute Ethical committee. (Human Studies) [Reference Notice.IEC /SC/2012/4/162.].This is a cross sectional study of single group. Subjects were enrolled in the study based on inclusion and exclusion criteria.

\section{Inclusion criteria}

All male patients aged more than 50 years presenting to orthopaedic department with

1. fracture neck of femur

2. Intertrochanteric fracture

\section{Exclusion criteria}

1. Patients who are taking calcium and vitamin D3 supplementation.

2. Patients with Secondary osteoporosis

3. Patients with Pathological fractures/Malignancy

4. Patients treated with small and large intestine surgeries \& renal problems.
This study was conducted from August 2012 to August 2013. All the patients were presenting to the department of orthopaedics in emergency and OPD with proximal femoral fractures satisfying inclusion criteria were included into the study.

The demographic details of the patient were collected and recorded. A valid informed consent in English and Vernacular language was taken in the format approved by the institute ethical committee.

The patients were then subjected to $\mathrm{x}$-ray pelvis with Bilateral Hips and lateral view of affected hip.

Five $\mathrm{ml}$ of Blood was collected from the ante cubital vein, the samples were centrifuged and serum was separated aliquoted and stored in $-70^{\circ}$ centigrade. The stored samples were processed by using immunodiagnostic 25hydroxy vitamin D total (D2 and D3) Enzyme linked Immunosorbentassay (ELISA) kit [KAP1971DIA source Immuno Assays S.A Rue du Bosquet, 2 B-1348 Louvain-la Neuve, Belgium] and the values obtained were expressed in $\mathrm{ng} / \mathrm{ml}$. Values of VitaminD obtained are shown into three groups as 020ng/ml-deficiency, 20ng/ml-30ng/ml as insufficiency and $>30 \mathrm{ng} / \mathrm{ml}$ as normal Reference.

\section{Vitamin D Assay}

Immunoenzymetricassay for in vitro quantitative measurement of 25-hydroxyvitaminD2and D3 $(25 \mathrm{OH}-$ D2and 25OH-D3) were processed in serum. Vitamin D is the generic term used to designate Vitamin D2 (Ergocalciferol) and vitamin $\mathrm{D} 3$ (Cholecalciferol).VitaminD2 is metabolised in a similar way to vitamin D3 both contribute to the overall vitamin D status of an individual it is the reason why it is very important to measure both forms of 25-hydroxy vitamin $\mathrm{D}$ equally for a correct diagnosis of vitamin $\mathrm{D}$ deficiency, insufficiency or intoxication.

\section{Principle}

The $25 \mathrm{OH}$ Vitamin D total ELISA is a solid phase enzyme linked immunosorbent assay performed on microtiterplate's .During first 2hours incubation step, at room temperature, total $25 \mathrm{OH}$ vitamin D (D2and D3) present in calibrators, controland sample is dissociated from binding serum proteins to fix on binding sites of a specific monoclonal antibody. After onewashing step a fixed amount of $25 \mathrm{OH}$ Vitamin D labelled with biotin in presence of horsedish peroxide (HRP), compete with 
unlabelled $25 \mathrm{OH} \quad$ vitamin D2and25OH vitaminD3present on the binding sites of the specific monoclonal antibody. After 30 minutes incubation at room temperature the microtiter plate is washed to stop the competition reaction the chromogenic solution (TMB) is added and incubated for 15 minutes. The reaction is stopped with the addition of stop solution and the microtiterplate is then read at the appropriate wave length.The amount of substrate turnover is determined colourimetrically by measuring the absorbance, which is inversely proportional to the total $25 \mathrm{OH}$ vitamin D(D2and D3)concentration. Calibration curve was plotted and the total $25 \mathrm{OH}$ vitamin (D2and D3) concentrations of the sample are determined by dose interpolation from the calibration curve.

\section{Statistical Analysis}

All the data were tabulated and recorded in Microsoft excel 2007. Analysis was done by IBMs statistical package for social sciences (SPSS) version 20.0 (2011).
Mean and standard deviation for all obtained values were done and correlation analysis was performed between hip fractures and vitamin D. All statistical analysis was carried out for $95 \%$ confidence interval and $\mathrm{p}$ value $<0.05$ was considered as significant.

\section{Observation and Results}

\section{Fracture types}

Of the total 41 patients evaluated 21 had fracture neck of the femur and 20 patients had intertrochanteric fractures.

\section{Age}

Total 41 patients included in the study. The youngest is 50years and oldest is 79years with a mean age of $62.20 y$ rs. Eighteen patients were in age group of 50$59 y r s, 15$ patients in age group of 60-69, 8 patients were in age group $>70 \mathrm{yrs}$.

\section{Distribution of fractures types in different age groups}

Of the total 18 patients in the age group 50-59, 7patients had intertrochanteric and 11 had fracture neck of the femur. In the age group 60-69, out of 15 patients 6 had intertrochanteric fractures and 9are neck of femur fractures. In the age group 70-79 out of 8 patients 7 had intertrochanteric and 1 had fracture neck of the femur same shown in table 1.

Table 1: Distribution of fractures types in different age groups

\begin{tabular}{|l|l|l|l|}
\hline Age(years) & Intertrochanteric & Neck of femur & Total \\
\hline $50-59$ & 7 & 11 & 18 \\
\hline $60-69$ & 6 & 9 & 15 \\
\hline $70-79$ & 7 & 1 & 08 \\
\hline
\end{tabular}

\section{Time duration between injuries to presentation:}

Patients included in the study presented to our department at variable time since injury.Nearly $82.92 \%$ (34) patients presented with 10 days of injury and remaining presented after 10 days.

\section{Distribution of vitamin D among different age groups:}

On analysis of Vitamin D in relation to different age groupswefound thatin the age group of50-59yrs4(22\%)showing $<20 \mathrm{ng} / \mathrm{ml}, 8$ (44\%) showing 20-30ng/ml and6(33\%)showing >30ng/ml .In age group of 60-69, 3(20\%)had $<20 \mathrm{ng} / \mathrm{ml}, 5(33.3 \%)$ had values between $20-30 \mathrm{ng} / \mathrm{ml}, 7(46.6 \%)$ had $>30 \mathrm{ng} / \mathrm{ml}$. In age group of $70-792(25 \%) \mathrm{had}$ $<20 \mathrm{ng} / \mathrm{ml}, 2(25 \%)$ had values between $20-30 \mathrm{ng} / \mathrm{ml}, 8(19.5 \%)$ had $>30 \mathrm{ng} / \mathrm{ml}$. We foundthere was no association between age and Vitamin D as $\mathrm{P}$ value is 0.593 as shown in table2.

Table 2: Distribution of vitamin D among different age groups

\begin{tabular}{|c|c|c|c|c|c|}
\hline Age & $<20 \mathrm{ng} / \mathrm{ml}$ & $20-30 \mathrm{ng} / \mathrm{ml}$ & $>30 \mathrm{ng} / \mathrm{ml}$ & Total & P value \\
\hline $50-59$ & 4 & 8 & 6 & 18 & \multirow{4}{*}{0.593} \\
\hline $60-69$ & 3 & 5 & 7 & 15 & \\
\hline $70-79$ & 2 & 2 & 4 & 8 & \\
\hline Total & 9 & 15 & 17 & 41 & \\
\hline
\end{tabular}




\section{Distribution of Vitamin D among fracture groups}

Of the total 41 patients 9 (22\%) had vitamin D level <20 ng /ml, 15 (36\%) had levels between 20ng-30ng/ml and 17 (41\%) had >30ng/ml. We didn't found association between fracture types and Vitamin D as P value was 0.489 same shown intable 3 .

Table3: Vitamin D level among fracture groups

\begin{tabular}{|l|l|l|l|l|}
\hline Fracture group & $\begin{array}{l}\text { VIT-D 0-20 } \\
\text { ng/ml }\end{array}$ & VIT-D20-30ng /ml & VIT-D>30ng/ml & P value \\
\hline Neck of femur(21) & 6 & 9 & 6 & 0.489 \\
\hline Intertrochanteric(20) & 3 & 6 & 11 & \\
\hline Total & $\mathbf{9}$ & $\mathbf{1 5}$ & $\mathbf{1 7}$ & \\
\hline
\end{tabular}

\section{Discussion}

This study investigated the association between hip fractures and Vitamin D in males more than 50years, with proximal femur fractures. The purpose of taking only male population in this study was that until now only limited studies on osteoporosis in elderly males with hip fracture are available in literature.As osteoporosis is well documented in elderly females than elderly males, onlythe elderly male patients more than 50years taken into consideration as this group of people are prone to have hip fractures due to trivial fall.

\section{Age}

The mean age group of patients in this study was 62.2(50-79) and all were below 80yrs males this is in par with other studies [9,10,11].In our review of the literature we found almost all studies have included all age groups but in our study we have included only patients with age between 50-80years. So the bias of age related osteoporosis might have avoided by this.

\section{Age distribution of fractures}

The fractures in this study group showed an age predilection as fracture neck of femur occurred mostly in younger age group (50-59) than older age group as compared to intertrochanteric which occurred mostly in age group 70 to 79 . This is in confirmation with existing literature. In our study we have included almost equal number of patients with fracture neck of femur and Intertrochanteric femur. As the age of the patients increases they are more prone to have Intertrochanteric fracture than neck of femur fracture following trivial fall. Although other factors like nature of injury, velocity of injury, muscle and fat cover around hip might also have contributed to this distribution of fracture pattern.

\section{Duration}

In this study of 41 patients, 34(82.91\%) presented within 10 days of injury and only 7(17.08\%) presented after 10 days. In our study 7 patients presented more than 10 days after injury and have been non ambulatory.So disuse osteopenia might have occurred in these patients in view of bed rest.

\section{Fracture correlation with Vitamin D}

In this study out of the total 41 patients Vitamin D deficiency was found in 9 patients, insufficiency in 15 patients and 17 patients had normal values. On analysing further we found that patient with neck of femur fracture had relatively low vitamin D (14 patients had Vit- D <30ng/ml) when compared to the patients with intertrochanteric fracture (9 patients had Vit- $\mathrm{D}<30 \mathrm{ng} / \mathrm{ml}$ ). Most of other studies have included females in their evaluation whereas only one study compared with male patients (cooper et al1998). We found almost equal incidence of fracture in both neck and trochanter region in spite of variable Vitamin D levels in our study population. 
Table 4: Comparison of this study with others in relation to fractures and vitamin D

\begin{tabular}{|c|c|c|c|c|c|}
\hline Study & Cooper et. al[12] & Erem et.al [11] & $\begin{array}{l}\text { Bakthiaroviya } \\
\text { et.al [10] }\end{array}$ & Rajesh et.al [9] & Present study \\
\hline Year & 1998 & 2002 & 2006 & 2010 & 2013 \\
\hline Population & $\begin{array}{l}\text { 41hipfracture } \\
\text { 40controls }\end{array}$ & $\begin{array}{l}21 \text { women with hip } \\
\text { fracture \& } \\
\text { 20postmenopausal } \\
\text { women }\end{array}$ & $\begin{array}{l}\text { 64fracturecases } \\
97 \text { controls }\end{array}$ & $\begin{array}{l}43 \\
\text { Hip fractures }\end{array}$ & $\begin{array}{l}41 \text { proximal } \\
\text { femoral } \\
\text { fractures }\end{array}$ \\
\hline Age(yrs) & 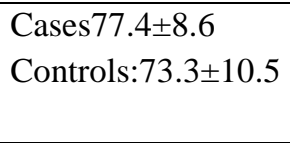 & $\begin{array}{l}\text { Cases:76.7 } \pm 6.5 y \\
\text { Controls: } 75.4 \pm 6.3\end{array}$ & $\begin{array}{l}\text { Cases:68.8 } \pm 9.5 \\
\text { Controls: } \\
70.2 \pm 8.3\end{array}$ & $62.2 \pm 12.3$ & $62.2 \mathrm{yrs}$ \\
\hline Sex & Only males & Only females & $\begin{array}{l}\text { Cases: } 69 \% \\
\text { femaleControls: } \\
55 \% \text { female }\end{array}$ & $\begin{array}{l}9 \text { men and } \\
34 \text { females }\end{array}$ & Only males \\
\hline $\begin{array}{l}\text { Vitamin } \\
\text { D }(\text { ng/ml }) \\
(\text { mean } \pm \text { SD })\end{array}$ & $\begin{array}{l}\text { Fracture patients: } \\
23.5 \pm 14.5 \\
\text { controls: } \\
35.75 \pm 23.5\end{array}$ & 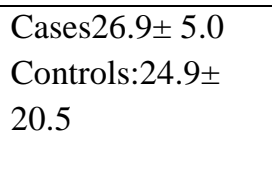 & $\begin{array}{l}\text { Cases:22.4 } \pm 11.4 \\
\text { Controls: } 28.1 \\
\pm 10.1\end{array}$ & $9.9 \pm 4.8$ & $31.4 \pm 17.3$ \\
\hline Results & $\begin{array}{l}\text { Men with hip } \\
\text { fractures had } \\
\text { significantly } \\
\text { lower25(OH) D } \\
\text { levels vs. controls. }\end{array}$ & $\begin{array}{l}\text { No significant } \\
\text { difference in } \\
25(\mathrm{OH}) \mathrm{D} \text { levels in } \\
\text { hip fracture } \\
\text { patients vs. } \\
\text { controls }\end{array}$ & $\begin{array}{l}25(\mathrm{OH}) \mathrm{D} \text { levels } \\
\text { significantly lower } \\
\text { in hip fracture } \\
\text { cases vs controls. . }\end{array}$ & $\begin{array}{l}96.7 \% \text { of } \\
\text { patients with } \\
\text { fractures has } \\
\text { vitamin } \\
\text { deficiency }\end{array}$ & $\begin{array}{l}58 \% \text { of patients } \\
\text { showing < } \\
\text { 30ng/ml. we } \\
\text { didn't found } \\
\text { significant } \\
\text { difference in } \\
\text { Vitamin D } \\
\text { levels in hip } \\
\text { fractures. }\end{array}$ \\
\hline
\end{tabular}

As our study was time bound we had few limitations in our study the sample size was small and this was a single centre study which will not reflective entire population. Duration of fracture at the time of presentation was not able to assess due to less sample size. The other factors like mechanism of injury velocity of injury soft tissue cover and muscle strength around hip region were not assessed. All these factors may have impact on the result of our study.

Despite these limitations, this study has several unique strengths. This study sample represents one of the few patients - based studies patients presenting to tertiary institute centre like JIPMER which represent almost south Indian population

Direct serum measures of serum vitamin D were used instead of indirect measures such as questionnairebased scales or food frequency intakes of vitamin Drich foods. As a result, the data more accurately reflect the impact of vitamin D status on hip fractures.

\section{Conclusion}

This was a cross sectional study aimed at studying the correlation of Serum vitamin D in males more than 50yrs with hip fractures who presented to the JIPMER. Vitamin D was estimated from blood. Mean and standard deviation for all obtained values was done and correlation analysis was performed between hip fractures and vitamin D. The results showed that most of the hip fractures were occurred in younger age group than older age group. Fracture neck of femur occurred in young patients compared to older patients as intertrochanteric fractures occurred mostly in older age.

Present study found that there is no statistically significant correlation between the vitamin $\mathrm{D}$ level and hipfractures inmalesmore than 50yrs $(\mathrm{p}=0.489)$. But the treatment of such patients with vitamin D supplements to prevent hip fractures is still debatable .However further studies in very large groups and controls may bring more light about it.

Funding: Nil, Conflict of interest: None Permission of Ethical committee: Yes 


\section{References}

1. Cauley JA. The determinants of fracture in men.JMusculoskelet Neuronal Interact. 2002 Mar;2(3):220-1.

2.Dhanwal DK, Dennison EM, Harvey NC, Cooper C. Epidemiology of hip fracture:Worldwide geographic variation. Indian J Orthop. 2011 Jan;45(1):15-22.

3. Sadat-Ali M, Al Elq AH, Al-Turki HA, Al-Mulhim FA, Al-Ali AK. Influence ofvitamin D levels on bone mineral density and osteoporosis. Ann Saudi Med. 2011Nov-Dec;31(6):602-8.

4. Cooper C, Campion G, Melton LJ 3rd. Hip fractures in the elderly: a world-wideprojection. Osteoporos Int. 1992 Nov;2(6):285-9.

5.Kanis JA, Johnell O, De Laet C, Johansson H, Oden A, Delmas P, Eisman J,Fujiwara S, Garnero P, Kroger H, McCloskey EV, Mellstrom D, Melton LJ, Pols H,Reeve J, Silman A, Tenenhouse A. A meta-analysis of previous fracture andsubsequent fracture risk.Bone. 2004 Aug;35(2):375-82.

6. Rola El-Rassi, GhassanBalikiGhada El-Hajj Fulheihan. Vitamin D status in Middle East and Africa. AM J med 2002;2:674-8.
7. Michael F Holick and Tai C Chen. Vitamin D deficiency: a worldwide problem with health consequences. Am J ClinNutr 2008;87(4):1080S-6S.

8. Lehmann B, Meurer M. Vitamin D metabolism. DermatolTher. 2010Jan-Feb;23(1):2-12.

9. Khadgawat R, Brar KS, Gahlo M, Yadav CS, Malhotra R, Guptat N, Tandon N. High prevalence of vitamin $\mathrm{D}$ deficiency in Asian-Indian patients with fragility hipfracture: a pilot study. J Assoc Physicians India. 2010 Sep;58:539-42.

10. Bakhtiyarova S, Lesnyak O, Kyznesova $\mathrm{N}$, Blankenstein MA, Lips P. Vitamin Dstatus among patients with hip fracture and elderly control subjectsinYekaterinburg, Russia. Osteoporosis Int. 2006;17(3):441-6.

11. Erem C, Tanakol R, Alagöl F, Omer B, Cetin O. Relationship of bone turn over parameters, endogenous hormones and vitamin D deficiency to hip fracture in elderly postmenopausal women. Int J Clin Pract. 2002 Jun;56(5):333-7

12. Cooper L, Clifton-Bligh PB, Nery ML, Figtree G, Twigg S, Hibbert E, Robinson BG. Vitamin D supplementation and bone mineral density in early postmenopausal women. Am J Clin Nutr. 2003 May;77 (5):1324-9.

\section{How to cite this article?}

Hari Krishna Mata, Gupta DC, Nataraj A.R. Correlation of serum vitamin D with hip fracturesin males more than 50 years of age. Int J Med Res Rev 2015;3(5):478-483. doi: 10.17511/ijmrr.2015.i5.092. 